\title{
Polymorphism of Deleted in Azoospermia-Like (DAZL) Gene in Ongole, Crossbred and Murrah Bulls used for Artificial Insemination in Andhra Pradesh, India
}

\author{
Sudhakar Krovvidi ${ }^{1}$, Vinoo, R. $^{1}$, Muralidhar Metta ${ }^{2}$, Deepthi, $\mathrm{Ch}^{1}{ }^{1}$, Surendra, $\mathrm{K}^{1}$ and Jayamaduri, $\mathrm{B}^{1}$ \\ ${ }^{1}$ Department of Animal Genetics and Breeding, NTR College of Veterinary Science, Gannavaram, Andhra Pradesh, INDIA \\ ${ }^{2}$ Department of Animal Genetics and Breeding, College of Veterinary Science, Garividi \\ (Sri Venkateswara Veterinary University, Andhra Pradesh, INDIA) \\ "Corresponding author: S Krovvidi; E-mail: vetsreesudha@rediffmail.com
}

Received: 04 April, 2021

Revised: 25 April, 2021

Accepted: 28 April, 2021

\begin{abstract}
Selection of elite crossbred bulls at young age is inevitable for uninterrupted supply of semen to vast bovine population for genetic improvement and production. Identification of sperm molecular biomarkers could be a better approach for selection of young bull for efficient use of resources. The present study was undertaken on 270 bulls of various genetic groups to assess the polymorphism at two loci of DAZL gene by PCR-RFLP. On restriction fragment analysis of 3'UTR/DedI polymorphism was observed in Ongole, Jersey, Jersey crossbred, Holstein, and Murrah bulls. HF crossbred bulls were monomorhic with fixation of $A$ allele and $C C$ genotype was evident only in Ongole bulls. In the bulls across the breeds studied the $A A$ genotype was predominant (90.0 to 99.0). PCR-RFLP of region comprising missense variant in exon 3 was performed with $B s t Y 1$ and the study revealed that all the bulls were monomorphic at the loci. Further studies to identify polymorphisms and evaluating their association might elucidate the role of DAZL SNPs as a marker for fertility traits in bulls.
\end{abstract}

\section{HIGHLIGHTS}

(0 DAZL gene polymorphism using PCR-RFLP was studied in 270 bulls.

0 Polymorphism at 3'UTR/DedI was observed in all the breeds except in HF crossbred bulls.

(0 Restriction digestion of missense variant in exon 3 with $B s t Y 1$ revealed all bulls are monomorphic.

Keywords: DAZL, PCR-RFLP, Ongole cattle, Murrah buffalo, Crossbred cattle

India is the world's largest milk producer and the total milk production was 187.75 million tons during 2018-2019 (Report, 2019) that was achieved through decades of efforts in genetic improvement of local cattle by crossbreeding with exotic cattle, and upgrading of indigenous buffaloes through artificial insemination. Implementing artificial insemination over a vast population of cattle and buffaloes demands continuous supply of frozen semen. In dairy production selection of young sires becomes a strenuous process in every bull station to have continuous supply of frozen semen of different genetic groups of cattle. One of the major obstacles faced during selection of young crossbred and buffalo bulls is that larger proportion of the young crossbred bulls are culled on the basis of poor semen quality and freezability. Moreover, infertility or sub-fertility is a major concern leading to bull disposal in India (Khatun, 2013; Ahlawat et al., 2017). Previous studies indicated poor libido and infertility in crossbred cattle than in indicine breeds (Mukhopadhyay et al., 2010; Elango et al., 2020) and decreasing fertility with increase in exotic inheritance in crossbred bulls (Mandal et al.,

How to cite this article: Krovvidi, S., Vinoo, R., Metta, M., Deepthi, Ch., Surendra, K. and Jayamaduri, B. (2021). Polymorphism of deleted in Azoospermia-like $(D A Z L)$ gene in Ongole, crossbred and Murrah bulls used for artificial insemination in Andhra Pradesh, India. J. Anim. Res. 11(3): 381-386.

Source of Support: None; Conflict of Interest: None 
2012). Large scale rejection of bulls after being maintained till the age at maturity results in huge loss of time, labour and cost. The ever increasing selection pressure on milk production and other economic traits is leading to an alarming decline in fertility of the dairy animals (Weigel, 2006). So, it's necessary to consider the fertility of an elite bull along with other economic traits. Detecting male fertility is difficult task as no single test is able to predict or diagnose sub-fertility (Selvaraju et al., 2018).

Markers for selection of high relative fertility traits in AI sires enhance production efficiency (Robinson and Buhr, 2005) and hence, identification of biomarker for fertility traits of sperm could be a better approach for selection of young bull. The Deleted in Azoospermia (DAZ) family consists of three genes: BOULE, Deleted in AzoospermiaLike $(D A Z L)$ and $D A Z$, among which $D A Z L$ gene and its homologues are essential for germ cell development in several species. Germ cell depletion and meiotic failure were reported in $D A Z L$ mutant mouse (McNeilly et al., 2000; Schrans-Stassen et al., 2001). Microdeletion and mutation of this gene has been frequently associated with the sterility in both vertebrates and invertebrates. Sixteen SNPs were identified in bovine DAZL gene (Liu and Ponce de León, 2007) that were associated with bull fertility. Given the importance of $D A Z$ genes, the present investigation was carried out to identify polymorphism of $D A Z L$ by polymerase chain reaction - restriction fragment length polymorphism (PCR-RFLP) in AI stud bulls. Studies in cattle-yaks suggested that the b-DAZL could be involved in spermatogenesis, and that transcription arrest of the gene is associated with male sterility (Zhang et al., 2008). Studies were conducted on $D A Z L$ gene as a source variation of male fertility in human (Teng et al., 2002; Tung et al., 2006), bulls (Sarova et al., 2018), rams (Yuan et al., 2020) however studies on polymorphism of the gene in livestock populations were scanty. Hence, the present study to identify polymorphism of DAZL gene in AI stud bulls was undertaken.

\section{MATERIALS AND METHODS}

The study does not warrant permission from Institutional Animal Ethics Committee as no experimentation was conducted on the animals but only observational study based on the DNA isolated from blood samples. The blood samples were collected aseptically from 270 bulls (Ongole:
54, Jersey: 30, Jersey crossbred: 56, Holstein Friesian (HF): 20, Holstein Friesian crossbred: 9, Murrah: 101) maintained at various Frozen Semen Bull Stations (FSBS) of Andhra Pradesh Livestock Development Agency (APLDA) located at Visakapatnam, Nandyal, Banavasi and Livestock Research Station (Sri Venkateswara Veterinary University), Lam, Guntur. Genomic DNA was isolated from blood samples as described by Miller et al. (1988) and stored at $-20^{\circ} \mathrm{C}$ until further use.

Multiple sequence alignment was performed to understand the homology based on the sequence information of $D A Z L$ genes in cattle and buffaloes available in NCBI. The variant data of Ensemble was screened for reported variants in $D A Z L$ genes and two SNP's (rs42740178 and rs440858806) were identified. The possibility to differentiate the alleles at polymorphic site using restriction enzyme was verified by using the online tool, NEBcutter V2.0 (Vincze et al., 2003). Primers were designed (Table 1) for the target SNP along with the flanking region using Primer3 and the genomic regions were amplified subjecting to PCR in a reaction volume of $10 \mu \mathrm{l}$ comprising of PCR mastermix (2x Taq Master Mix Red, Amplicon, Denmark) along with 5 pmol of each primer and $1 \mu 1$ of template DNA. At every PCR setup a negative control was run along with the samples. The conditions for amplification included initial denaturation at $94{ }^{\circ} \mathrm{C} / 3 \mathrm{~min}$, followed by 35 cycles: $94{ }^{\circ} \mathrm{C} / 30 \mathrm{~s}, 55{ }^{\circ} \mathrm{C} / 45 \mathrm{~s}, 72{ }^{\circ} \mathrm{C} / 30 \mathrm{~s}$, for $3^{\prime} \mathrm{UTR}$ region; 94 ${ }^{\circ} \mathrm{C} / 30 \mathrm{~s}, 60^{\circ} \mathrm{C} / 45 \mathrm{~s}, 72{ }^{\circ} \mathrm{C} / 30 \mathrm{~s}$ for missense mutation region, and a final extension for each at $72{ }^{\circ} \mathrm{C} / 10 \mathrm{~min}$. Amplicon of each sample $(10 \mathrm{~mL})$ was subjected to RFLP with 2 units of DdeI and BstY1 to genotype each animal with respect to the 3' UTR and missense variants respectively. All the digested samples were electrophoresed in agarose gel and visualized in gel image system (Omega Fluor ${ }^{\mathrm{TM}}$ Plus Documentation Systems, BioExpress, USA).

\section{RESULTS AND DISCUSSION}

In the present study the regions of $D A Z L$ gene spanning rs42740178 (3'UTR) and rs440858806 (missense mutation) were amplified in all the genetic groups. The corresponding PCR products observed were $300 \mathrm{bp}$ and 364 bp respectively.

The restriction fragment pattern of 3'UTR/DedI corresponding to three genotypes $A A(243,39$ and $18 \mathrm{bp})$, $A C(243,160,83,39,18 \mathrm{bp})$ and $C C(160,83,39$ and 18 
Table 1: Details of primers designed against SNP regions in $D A Z L$ gene

\begin{tabular}{llll}
\hline Sl. No. & Loci & Primer Sequence & Product (bp) \\
\hline 1 & 3'UTR & F: GGGCACTTTCAAATTCTGAGG & 300 \\
& (rs42740178) & R: CCTTGGAAGGAAAGGGTAGC & 364 \\
\hline
\end{tabular}

Table 2: Distribution of genotypes and allele frequencies at 3'UTR /DedI locus in cattle and buffaloes bulls

\begin{tabular}{|c|c|c|c|c|c|c|c|c|c|c|c|}
\hline \multirow[t]{2}{*}{ Breed / Group } & \multirow{2}{*}{$\begin{array}{l}\text { Number of } \\
\text { animals (n) }\end{array}$} & \multicolumn{3}{|c|}{ Observed Genotypic frequency } & \multicolumn{2}{|c|}{$\begin{array}{l}\text { Allele } \\
\text { frequency }\end{array}$} & \multicolumn{3}{|c|}{$\begin{array}{c}\text { Expected Genotype } \\
\text { frequency }\end{array}$} & \multirow[t]{2}{*}{$\chi^{2}$ value } & \multirow[t]{2}{*}{$P$ value } \\
\hline & & $\overline{A A}$ & $A C$ & $C C$ & $A$ & $C$ & $A A$ & $A C$ & $C C$ & & \\
\hline Jersey & 30 & $93.3(28)$ & $6.7(2)$ & $-(0)$ & 0.97 & 0.03 & 28.01 & 1.97 & 0 & $0.02^{\mathrm{NS}}$ & 0.89 \\
\hline Jersey crossbred & 56 & $98.2(55)$ & $1.8(1)$ & $-(0)$ & 0.99 & 0.01 & 55.00 & 0.99 & 0.00 & $0.004^{\mathrm{NS}}$ & 0.94 \\
\hline $\mathrm{HF}$ & 20 & $90.0(18)$ & $10.0(2)$ & $-(0)$ & 0.95 & 0.05 & 18.05 & 1.9 & 0.05 & $0.03^{\mathrm{NS}}$ & 0.86 \\
\hline HF crossbred & 9 & $100.0(9)$ & - & - & 1 & 0 & - & - & - & - & - \\
\hline Ongole & 54 & $94.44(51)$ & $3.70(2)$ & $1.86(1)$ & 0.96 & 0.04 & 50.1 & 3.9 & 0.1 & $12.82^{*}$ & 0.0004 \\
\hline Murrah & 101 & $99.0(100)$ & $1.0(1)$ & - & 0.99 & 0.01 & 100 & 1.0 & - & $0.001^{\mathrm{NS}}$ & 0.96 \\
\hline
\end{tabular}

Figures in parentheses are the number of animals, NS: Not significant $(\mathrm{P}>0.05) *$ Significant $(\mathrm{P}<0.05)$.

Table 3: Population indices at 3'UTR/DedI

\begin{tabular}{llllllll}
\hline Breed & $\begin{array}{l}\text { Observed } \\
\text { homozygosity }\end{array}$ & $\begin{array}{l}\text { Observed } \\
\text { heterozygosity }\end{array}$ & $\begin{array}{l}\text { Expected } \\
\text { homozygosity }\end{array}$ & $\begin{array}{l}\text { Expected } \\
\text { heterozygosity }\end{array}$ & Ne & PIC & F IS \\
\hline Jersey & 0.93 & 0.07 & 0.93 & 0.07 & 1.06 & 0.06 & -0.03 \\
Jersey cross & 0.98 & 0.02 & 0.98 & 0.02 & 1.01 & 0.02 & -0.01 \\
HF & 0.9 & 0.10 & 0.9 & 0.09 & 1.10 & 0.09 & -0.05 \\
HF cross & 1 & 0 & 1 & 0 & 1 & - & - \\
Ongole & 0.96 & 0.04 & 0.93 & 0.07 & 1.07 & 0.07 & 0.48 \\
Murrah & 0.99 & 0.01 & 0.99 & 0.01 & 1.01 & 0.02 & -0.01 \\
\hline
\end{tabular}

bp) indicative of presence of polymorphism was observed (Fig. 1). Polymorphism was evident in Murrah bulls and all the studied genetic groups of cattle, except in HF crossbred. All the HF crossbred bulls were monomorphic and were typed to $A A$ genotype. None of the Exotic or crossbred bulls belonged to $C C$ genotype. The observed genotype and allele frequencies are presented in Table 2. In the genetic groups examined, the $A$ allele frequency was almost nearing to fixation in exotic, and crosses with exotic bulls ( 0.95 to 0.99 ). Fixation of $A$ allele was observed in HF crossbred bulls. In none of the exotic and crossbred population under study $C C$ genotypes could be observed and only one bull belonging to Ongole breed was genotyped as $C C$. The $300 \mathrm{bp}$ PCR amplicon of the DAZL gene in Murrah yielded a two different band pattern. Bands of 243, 39 and $18 \mathrm{bp}$ were observed in almost all samples corresponding to the $A A$ genotype. Only one animal was genotyped to heterozygous $A C$. At the same locus (rs42740178) in 3' UTR region the frequency of $\mathrm{C}$ and A alleles in IRBT (Iranian Bos taurus) population from NextGen project (http://feb2021.archive.ensembl. org/Bos_taurus/Variation/ Population? $\mathrm{r}=1: 153640009$ $153641009 ; \mathrm{v}=\mathrm{rs} 42740178 ; \mathrm{vdb}=$ variation; $\mathrm{vf}=24718109$ ) was 0.31 and 0.69 . The $A$ allele frequency in the studied zebu bulls, exotic and crosses involving exotic bulls and in Murrah bulls was higher than that was reported in IRBT population. 


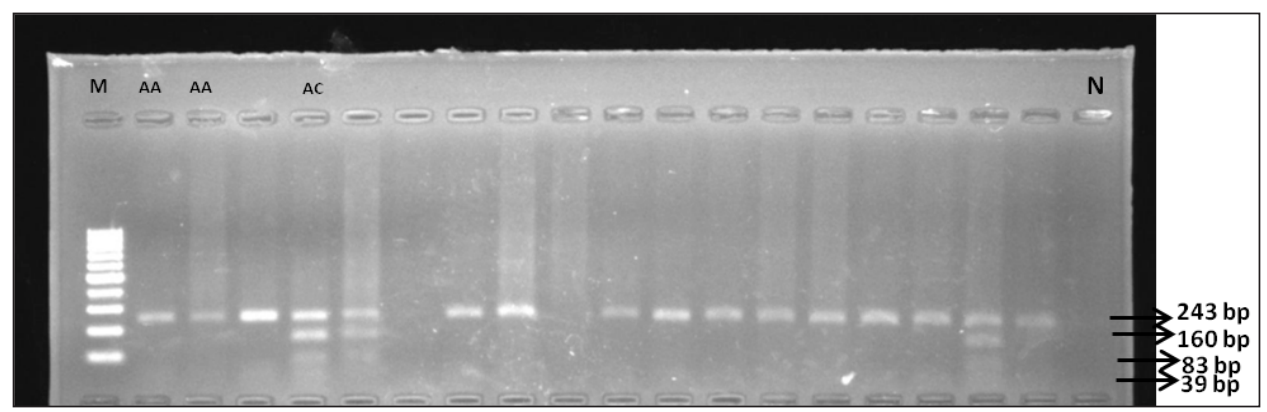

(a) Photograph depicting $A A(243,39,18 \mathrm{bp})$ and $A C(243,160,83,39,18 \mathrm{bp})$ genotypes. Genotype indicated at the top of the lane; M: 100 bp marker, N: Negative control

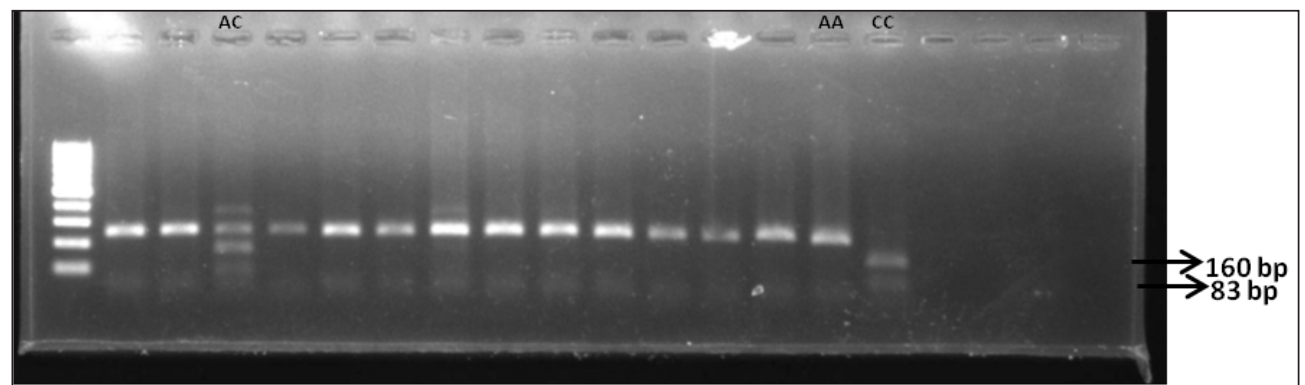

(b) Photograph depicting $A A, A C$ and $C C(160,83,39$ and $18 \mathrm{bp})$ genotypes. Genotype indicated at the top of the lane; M: $100 \mathrm{bp}$ marker, $\mathrm{N}$ : Negative control

Fig. 1: RFLP pattern of 3'UTR-DAZL / DedI locus in different genetic groups

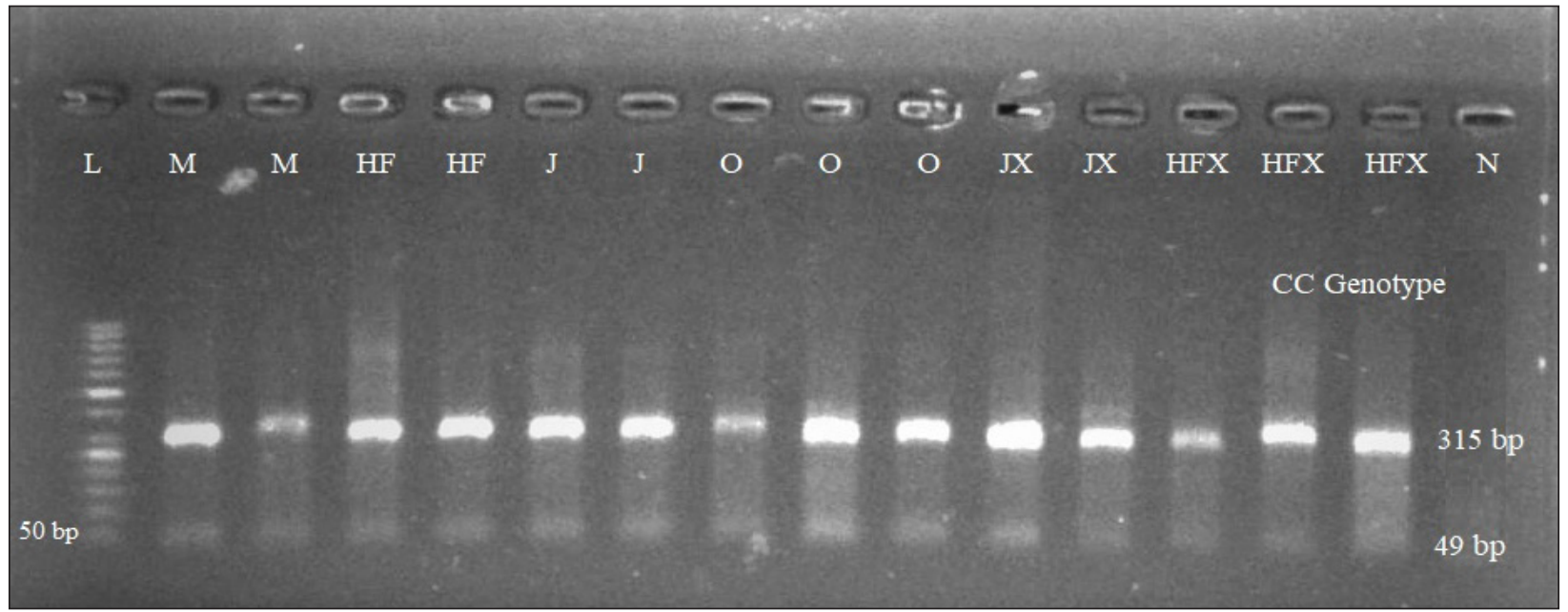

Genotype shown at the top of the lane; L:50 bp marker, O: Ongole, H: HF, HX: HF crossbred, J: Jersey, JX: Jersey crossbred, M: Murrah, $\mathrm{N}$ : Negative control

Fig. 2: RFLP pattern of $D A Z L / B s t Y 1$ in different genetic groups 
The population genetic indices at 3'UTR /DedI of DAZL locus in the examined groups of cattle and buffalo bulls for each genetic group under study and were presented in Table 2 and 3 . The expected and observed genotypic frequencies in all the exotic bulls and crosses with exotic bull groups were almost similar. The analysis on 3'UTR /DedI locus revealed that the present populations were consistent with Hardy-Weinberg equilibrium $(\mathrm{P}>0.05)$ except for indigenous cattle i.e. Ongole bulls $(\mathrm{P}=0.004)$. The $C$ allele is found to be rare allele in the Murrah population. The distribution of 3'UTR variant (rs42740178) genotypic frequencies in all the cattle populations was almost equal to the expected heterozygosity (Table 3 ). The observed heterozygosity was less than expected $(\mathrm{P}<0.01)$ in Ongole bull population. The effective number of alleles $(\mathrm{Ne})$ across the studied genetic groups ranged between 1.069 (HFx) to 1.1 (HF). Murrah buffalo bulls were with highest heterozygosity among the studied populations. The estimates of polymorphic information content (PIC) values varied from 0.01 (Murrah, \& Jersey crosses) to 0.09 (HF) among the different cattle populations which is considered to be lesser degree of informativeness for a marker. The Ongole bulls were observed to be in HardyWeinberg disequilibrium $(\mathrm{P}<0.05)$ and the $F_{\text {IS }}$ values were positive in this breed indicating heterozygote deficiency.

Digestion of DAZL PCR amplicon (364 bp) encompassing missense variant in exon 3 was performed with Bst $Y 1$ restriction enzyme to identify the polymorphism and the study revealed only $C C$ genotypes (315 bp and $49 \mathrm{bp}$ ) in all the animals (Fig. 2). As all the genetic groups were monomorphic further studies could not be conducted.

Some of the earlier studies in human revealed that the SNPs within DAZL have significant influence on male fertility (Zhu et al., 2014) and those with non-obstructive azoospermia showed a declining expression of $D A Z L$ in the testis (Hashemi et al., 2018). In studies involving livestock, a significant association between SNPs of DAZL and epididymis weight was reported in rams (Yuan et al., 2020). The biometrical traits of epididymis are affecting the ejaculated semen volume and sperm motility (Ytournel et al., 2014) and sperm abnormality (Waldner et al., 2010). Owing to the highly conserved nature of the gene among species capture of sire fertility phenotypes in dairy herds utilizing $D A Z L$ gene polymorphism will contribute for genomic selection for male fertility. Ogoreves et al. (2011) reported nine SNPs in 3' UTR region of DAZL gene in cattle and opined that it is the most polymorphic candidate with substantial level of variation and affecting male reproductive traits.

\section{CONCLUSION}

The present study revealed a substitution of $\mathrm{C} \rightarrow \mathrm{A}$ at position 2519 position in 3'UTR region ( $r$ 42740178) in all the bulls except in HF crossbred. HF crossbred bulls were monomorphic and were typed to $A A$ genotype. In Murrah bulls only one was heterozygous $(A C)$ and interestingly none of the other exotic or crossbred bulls belonged to $C C$ genotype. Since, the sequences within the UTRs mediate the translational regulation of mRNAs further studies on polymorphism, differential expression and association may shed light on role in bull fertility.

\section{ACKNOWLEDGEMENTS}

Authors acknowledge the financial support extended by the University under "Minor Research Projects". The authors also thank the Chief Executive Officer, AP Livestock Development Agency, Guntur, Andhra Pradesh for according permission to collect the samples.

\section{REFERENCES}

Ahlawat, S., De S., Sharma, P., Sharma, R., Arora, R., Kataria, R. S., Datta, T.K. and Singh, R.K. 2017. Evolutionary dynamics of meiotic recombination hotspots regulator PRDM9 in bovids. Mol. Genet. Genom., 292 (1): 117-131.

Braundmeier, A.G. and Miller, D.J. 2001. The search is on: finding accurate molecular markers of male fertility. J. Dairy Sci., 84(9): 1915-25.

Elango, K., Kumaresan, A., Sharma, A., Nag, P., Prakash, M.A., Sinha, M., Manimaran, A., John, P., Ebenezer, S.K., Sakthivel, J., Sellappan, S., Ramesha, K. and Datta, T. 2020. Sub-fertility in crossbred bulls: deciphering testicular level transcriptomic alterations between zebu (Bos indicus) and crossbred (Bos taurus $\times$ Bos indicus) bulls. BMC Genom., 21(502).

Hashemi, M.S., Mozdarani, H., Ghaedi, K. and Nasr-Esfahani, M.H. 2018. Among seven testis-specific molecular markers, SPEM1 appears to have a significant clinical value for prediction of sperm retrieval in azoospermic men. Andrology, 6: $890-895$.

Khatun, M., Kaur, S., Kanchan, and Mukhopadhyay, C.S. 2013. Subfertility problems leading to disposal of breeding bulls. Asian Australas J Anim Sci., 26(3): 303-308. 
Liu, W.S. and Ponce de León, F.A. 2007. Mapping of the bovine Y chromosome. Electron. J. Biol., 3 (1): 5-12.

Mandal, D.K., Tyagi, S. and Kumar, M. 2012. Spermiogram of low a vis high sperm output crossbred frieswal bulls. Indian J. Dairy Sci., 65(4): 314-318.

McNeilly, J.K., Saunders, P.T., Taggart, M., Cranfield, M., Cooke, H.J. and McNeilly, A.S. 2000. Loss of oocytes in DAZL knockout mice results in maintained ovarian steroidogenic function but altered gonadotropin secretion in adult animals. Endocrinology., 141(11): 4284 - 4294.

Miller, S.A., Dykes, D.D. and Polesky, H.F.R.N. 1988. A simple salting out procedure for extracting DNA from human nucleated cells. Nucl. Acids Res., 16(3): 1215.

Mukhopadhyay, C.S., Gupta, A.K., Yadav, B.R., Khate, K., Raina, V.S., Mohanty, T.K. and Dubey, P.P. 2010. Subfertility in males: an important cause of bull disposal in bovines. Asian Australas. J. Anim. Sci., 23(4): 450-455

Ogorevc, J., Dovc, P. and Kunej, T. 2011. Comparative genomics approach to identify candidate genetic loci for male fertility. Reprod Domest. Anim., 46(2): 229-239.

Report, 2019. Basic Animal Husbandry Statistics, Government of India, Ministry of Agriculture Department of Animal Husbandry, Dairying and Fisheries, Krishi Bhawan, New Delhi.

Robinson, J.A. and Buhr, M.M. 2005. Impact of genetic selection on management of boar replacement. Theriogenology, 63(2): 668-78.

Sarova, N., Ahlawat, S., Grewal, A., Sharma, R. and Arora, R. 2018. Differential promoter methylation of DAZL gene in bulls with varying seminal parameters. Reprod. Domest. Anim., 53(4): 914-920.

Schrans-Stassen, B.H., Saunders, P.T., Cooke, H.J. and de Rooij, D.G. 2001. Nature of the spermatogenic arrest in DAZL-/mice. Biol, Reprod., 65(3): 771-776.

Selvaraju, S., Parthipan, S., Somashekar, L., Binsila, B.K., Kolte, A.P., Arangasamy, A., Parameshwaraiah, R.J. and Krawetz, S.A. 2018. Current status of sperm functional genomics and its diagnostic potential of fertility in bovine (Bos taurus). Syst. Biol. Reprod. Med., 64(6): 484- 501.
Teng, Y.N., Lin, Y.M., Lin, Y.H., Tsao, S.Y., Hsu, C.C., Lin, S.J., Tsai, W.C. and Kuo, P.L. 2002. Association of a singlenucleotide polymorphism of the deleted-in-azoospermia-like gene with susceptibility to spermatogenic failure. J. Clin. Endocrinol. Metab., 87(11): 5258-5264.

Tung, J.Y., Luetjens, C.M., Wistuba, J., Xu, E.Y., Reijo Pera, R.A. and Gromoll, J. 2006. Evolutionary comparison of the reproductive genes, DAZL and BOULE, in primates with and without DAZ. Dev. Genes Evol., 216(3): 158-168.

Vincze, T., Posfai, J. and Roberts, R.J. 2003. NEBcutter: a program to cleave DNA with restriction enzymes. Nucleic Acids Res., 31: 3688-3691.

Waldner, C.L., Kennedy, R.I. and Palmer, C.W. 2010. A description of the findings from bull breeding soundness evaluations and their association with pregnancy outcomes in a study of western Canadian beef herds. Theriogenology, 74(5): 871-83.

Weigel, K.A. 2006. Prospects for improving reproductive performance through genetic selection. Anim. Reprod. Sci., 96(3-4): 323-330.

Ytournel, F., Brunet, E., Derks, P. and Huisman, A. 2014. Testes size as predictor for semen production of boars and relation to female reproductive traits. In Proceedings of the 10thWorld Congress on Genetics Applied to Livestock Production, Vancouver, BC, Canada, 17-22 August.

Yuan, Z., Luo, J., Wang, L., Li, F., Li, W. and Yue, X. 2020. Expression of DAZL gene in selected tissues and association of its polymorphisms with testicular size in $\mathrm{Hu}$ sheep. Animals, 10(4): 740.

Zhang, Q.B., Li, Q.F., Li, J.H., Li, X.F., Liu, Z.S., Song, D. and Xie, Z. 2008. b-DAZL: A novel gene in bovine spermatogenesis. Prog Nat Sci., 18(10): 1209-1218.

Zhu, Y., Ma, M., Wan, L., Zhang, D., Zhao, L., Wei, L. and Li, L. 2014. Analysis of DAZL SNP260 and SNP386 in infertile Chinese males using multi-analyte suspension array. Mol. Med. Rep., 10(6): 2949-2954. 